\title{
Loyalty in Education as a Business
}

\author{
Alberto Un Jan, Doctor ${ }^{1}$, Vilma Contreras, B.S. ${ }^{1}$, and Vilma Un Jan, Student ${ }^{2}$. \\ ${ }^{1}$ Universidad Nacional de Ingeniería, Perú, eun-jan@uni.edu.pe, vcontreras467@gmail.com \\ ${ }^{2}$ Florida Gulf Coast University, USA, vilmaunjan@gmail.com \\ * Corresponding author
}

\begin{abstract}
This paper examines variables that influence on students' loyalty in education at the university. The causes of students' intention to stay and intention to recommend are identified. The instrument used is a questionnaire based on previous studies, from which finally 23 questions are obtained and measured. Correlation between variables confirms the influence of quality and social influence on customer satisfaction and loyalty. Quality is perceived by the student as academic quality and administrative quality. Students' intention to stay and intention to recommend are identified as a behavior of loyalty. The research was done among students at private universities in Lima, Peru. Public universities were not included. Economic factors and costs were not included. To improve loyalty in education, Quality of the product and Quality of the service are relevant. Quality of the service means quality of academic and administrative service. Loyalty in education, as in any other business, is necessary to keep clients, in this case students. Administrative and academic authorities must devote resources to improve customer satisfaction and reputation. Loyalty is understood and measured as intention to stay and intention to recommend. The authors did not find similar studies in Peru.

Keywords: Loyalty, intention to recommend, intention to stay, electronic word of mouth (eWOM).
\end{abstract}

\section{INTRODUCTION}

This paper aims to examine the variables that influence on students' loyalty in education at the university. Education at universities, seen as a business, faces aspects of marketing, loyalty and desertion. The desertion of university students has been studied in Peru [1] and in Latin America and Caribe [2]. Around 40 to 50 thousand students abandon their studies every year in Peru [3]. In a more detailed study, Heredia Alarcón, Andía Ticona, Ocampo Guabloche, Ramos-Castillo, Rodríguez Caldas, Tenorio and Pardo Ruiz [4] report about the desertion of students from health sciences careers in Peru; they study nine Peruvian universities and find $10.2 \%$ of students' desertion in medicine, $11,11 \%$ in obstetrics, $9.91 \%$ in nursing and $5.64 \%$ in dentistry; $10 \%$ on average. Section II in this paper, Research Problem, proposes the research question. Then, Section III Materials and Methods, develops the instrument for measuring the relationship between variables, describes the sample, applies a questionnaire and applies the statistical methods to the answers collected. Section IV Results analyses the statistical results, and identifies the hypotheses that are confirmed. Section V Discussion shows the resulting model, limitations, future research, and administrative interpretation. Finally, the conclusions are presented.

\section{RESEARCH PROBLEM}

\section{A. Loyalty}

Students' satisfaction with their major curriculum and perceptions of career readiness are important drivers of recruitment, retention and rankings [5]. The causes for desertion of university students, as opposed to loyalty, need to be studied considering students as clients, and education as a business. Mohamad and Awang [6] studied high level learning institutions in Malaysia, and argue that service quality distinguishes institutions from competitors; in this case quality precedes student satisfaction, and produces student loyalty. Sultan and Wong [7] took the research by LeBlanc and Nguyen [8] as start point to measure quality in education. Sultan and Wong found that satisfaction and loyalty have chain effects. De Jager and Gbadamosi [9] studied the gaps in students' perception of service quality, and the predictors of service quality and students' satisfaction. Their results show that the most important predictors of overall students' satisfaction are intention to leave, trust in management, and perception of readiness for change. Also, Ahmed, Illahe, Ahmad, Nadeem and Rehman [10] state that service quality influences on the student loyalty.

Researchers in different countries have studied loyalty at higher education levels. From the research list in table I, loyalty is related to: a) Word of mouth (Al-Alak [11]; Phadke [12]), b) Intention to recommend (Phadke [12]; Endres, Chowdhury, Frye and Hurtubis [13]), c) Attraction back for further studies (Phadke, [12]), and d) Long term relationship (Al-Alak [11]; Phadke [12]; Chuah and Ramalu [14]).

The variables that influence on loyalty are: a) Student Satisfaction (Al-Alak [11]; Endres et al., [13]; Nesset and Helgesen [15]), b) Reputation (Nesset and Helgesen [15]), c) Trust (Al-Alak [11]; Rojas-Méndez, Vásquez-Párraga, Kara and Cerda-Urrutia [16]), d) Commitment (Rojas-Méndez et al. [16]), e) Service quality (Chuah and Ramalu [14]), and f) Student satisfaction (Chen [17]). 
TABLE I

RESEARCHES

\begin{tabular}{|l|l|l|}
\hline \multicolumn{1}{|c|}{ Authors } & \multicolumn{1}{|c|}{ What they studied } & \multicolumn{1}{c|}{ Result } \\
\hline Al-Alak [11] in Jordan & $\begin{array}{l}\text { The impact of marketing actions } \\
\text { on relationship quality }\end{array}$ & $\begin{array}{l}\text { Relationship marketing activities lead to student } \\
\text { satisfaction and trust, and also to relationship } \\
\text { continuity, and positive word of mouth. }\end{array}$ \\
\hline $\begin{array}{l}\text { Phadke [12] in } \\
\text { Bangalore, India }\end{array}$ & $\begin{array}{l}\text { Student loyalty in a competitive } \\
\text { market to retain students }\end{array}$ & $\begin{array}{l}\text { Student loyalty refers to indicators that signal } \\
\text { students intention to: 1) Recommend the } \\
\text { college to others, 2) Engage in positive word of } \\
\text { mouth, 3) Return to college for further } \\
\text { education. }\end{array}$ \\
\hline $\begin{array}{l}\text { Endres et al. [13] in } \\
\text { USA }\end{array}$ & $\begin{array}{l}\text { Students enrolled in online } \\
\text { MBA courses at a university in } \\
\text { Midwest, USA }\end{array}$ & $\begin{array}{l}\text { Satisfaction predicted student intention to } \\
\text { recommend the course, faculty and university to } \\
\text { others }\end{array}$ \\
\hline $\begin{array}{l}\text { Chuah and Ramalu [14] } \\
\text { in Malaysia }\end{array}$ & $\begin{array}{l}\text { Relationship between service } \\
\text { quality and the level of student's } \\
\text { satisfaction }\end{array}$ & $\begin{array}{l}\text { The better the service quality provided by the } \\
\text { university, the higher the level of student } \\
\text { satisfaction to sustain customer loyalty. }\end{array}$ \\
\hline $\begin{array}{l}\text { Nesset and Helgesen } \\
\text { [15] in Norway }\end{array}$ & $\begin{array}{l}\text { Student loyalty } \\
\text { Rojas-Méndez et al. [16] } \\
\text { student loyalty }\end{array}$ \\
\hline $\begin{array}{l}\text { Student loyalty in higher } \\
\text { education institutions }\end{array}$ & $\begin{array}{l}\text { Perceived service quality and student } \\
\text { satisfaction do not translate directly into student } \\
\text { loyalty, but rather, indirectly through the } \\
\text { mediation of trust and commitment }\end{array}$ \\
\hline Chen [17] in Taiwan & $\begin{array}{l}\text { Relationships among marketing } \\
\text { strategies, student satisfaction, } \\
\text { and loyalty in higher education }\end{array}$ & $\begin{array}{l}\text { Student satisfaction is the positive attitude that } \\
\text { encapsulates students' general feeling about } \\
\text { their experiences of higher education }\end{array}$ \\
\hline
\end{tabular}

\section{B. From loyalty to continuity}

Student loyalty is the combination between student willingness to provide positive words of mouth about the institution and recommendation concerning educational institution to family, friends, employers, and organizations whenever opportunities are [18]. Loyalty involves an identifiable intention to behave, such as repurchasing a specific brand or providing a financial or non-financial support to one's alma mater [16]. Intention is expressed and measured as continuity [11]: Intention to recommend and intention to stay (as opposed to intention to flee). Social influence is also a variable that influences quality. However, the participation of social influence will be determined after collecting the data.

The research question is:

What is the influence of quality on loyalty in education as a business?

The hypotheses are:

H1: Quality of the product is positively related to customer satisfaction

$\mathrm{H} 2$ : Quality of the product is positively related to reputation

H3 a: Quality of the academic service is positively related to customer satisfaction

H3 b: Quality of the administrative service is positively related to customer satisfaction

H4 a: Quality of the academic service is positively related to reputation
H4 b: Quality of the administrative service is positively related to reputation

H5a: Customer satisfaction is positively related to intention to recommend

H5b: Customer satisfaction is positively related to intention to stay

H6a: Reputation is positively related to intention to recommend

H6b: Reputation is positively related to intention to stay

Fig. 1 shows the initial model proposed.

\section{MATERIALS AND METHODS}

\section{A. Instruments}

This research will use the questionnaire suggested by LeBlanc and Nguyen [8], with some modifications. The questionnaire has to be reduced to highlight quantitative aspects. The questionnaire used by LeBlanc and Nguyen contains 31 variables related to different aspects of the business school's service offering, such as projected image, physical facilities and instruments, operating procedures, service delivery, faculty and administrative personnel. From the questionnaire used by LeBlanc and Nguyen, only 12 out of 31 questions have been selected for this research. The variables of interest selected are those related to quality of administrative service, quality of academic service, quality of product, and reputation. The 12 questions selected are shown in table II. 


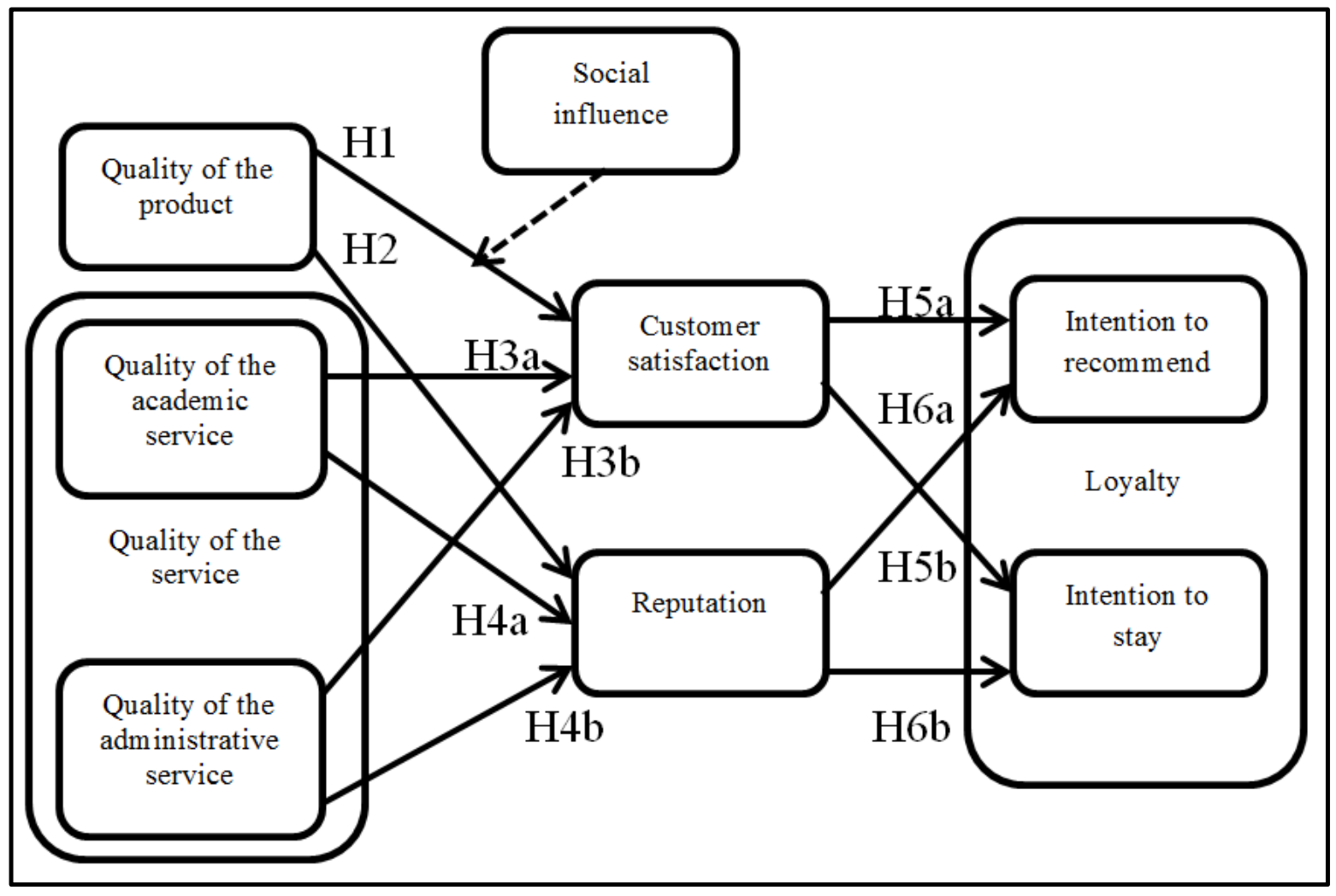

Fig. 1 Initial model

TABLE II

VARIABLES RELATED TO QUALITY AND REPUTATION, SELECTED FROM LEBLANC AND NGUYEN [8].

\section{F1 Contact with faculty personnel}

- $\quad$ Professors are friendly and courteous

Communication skills: courses are well taught

Academic credentials of professors are good F2 Reputation

- $\quad$ School has organizational culture, beliefs and values

- Business school is involved in community

- Administration has students' best interest at heart F4 Contact with administrative personnel

- Personnel is always available

- Personnel is friendly and courteous

- Personnel has the capacity to solve problems when they arise

F5 Curriculum
good

- Number of courses offered is adequate

- $\quad$ Objectives of programmes are explained to students

Education business is transforming student loyalty into an important strategic theme for universities and colleges, as pointed out by Nesset and Helgesen [15], who use three items to measure loyalty: a) probability of recommending the university to friends and acquaintances, b) probability of attending the same university if starting again, and c) probability of attending new courses or continuing education at the same university. Instead of probability, intention in mentioned by other authors and will be preferred in this research. For example, Brown and Mazzarol [19] include referral and repurchase intentions into the loyalty construct. Endres et al. [13], page 305, hypothesize that: "Student behavioral intention to recommend the course to others is predicted by the satisfaction with course materials, learning practices, and student-to-student interaction, but not by their satisfaction with faculty practices or on line tools." They also propose that students' satisfaction with online tools predicts their intention to recommend the university.

Al-Alak [11] develops a list of variables that may influence relationship quality and may be affected by relationship quality. To measure consequences of relationship quality, the variables relationship continuity, and word of mouth are used. Relationship continuity is measured with the questions: 1) I believe a university employee will provide better service in the future; 2) I will not switch to another university; and 3) I will always be proud of this university. For Word of mouth, the questions used are: 1) I want to recommend this university to others; 2) I want to tell other persons about good things of this university.

According to Balujeva [20], one way to encourage students' positive electronic word of mouth (eWOM) about the university is to strengthen their sense of belongingness to university's online community. Due to low usage of other social media platforms (LinkedIn, Instagram, Twitter, VKontakte, and YouTube), the results of Balujeva's study are based solely on Facebook; however, she generalizes the idea to other social media platforms as well. In other words, along with the growth of students' sense of belongingness to the Lapeenranta University of Technology (LUT) community on those 
platforms, the university will be able to generate more positive eWOM in social media. The questions related to loyalty, in the questionnaire by Balujeva, are shown in table III.

TABLE III

VARIABLES RELATED TO LOYALTY, SELECTED FROM BALUJEVA [20].

\begin{tabular}{|l|}
\hline \multicolumn{1}{|c|}{ eWOM activity intention } \\
\hline$-\quad$ I won't miss an opportunity to mention LUT on \\
(Facebook) \\
I won't miss an opportunity to 'like' posts made by \\
LUT on (Facebook) \\
I won't miss an opportunity to 'share' posts made by \\
LUT on (Facebook) \\
When posting about LUT on (Facebook), I will \\
describe it in detail \\
\hline Positive eWOM intention \\
\hline I will speak of good sides of LUT on (Facebook) \\
I will mostly say positive things to others about LUT \\
on (Facebook) \\
I will speak favorably of LUT to others on \\
(Facebook)
\end{tabular}

In another research conducted by Endres et al. [13] the online survey instrument contains three questions about their behavioral intentions to be used as the dependent variables in the study: 1) Will you recommend the course to others? 2) Will you recommend this faculty member to others? 3) Will you recommend the university to others? Students were asked to circle yes or no as a response to each question. According to the recommendation by Endres et al. [13], a student may want to give a response that corresponds to 'it depends' or 'to some people'. Therefore, future researchers may use a continuous scale to measure behavioral intention. Following this recommendation, in this current study, instruments based on Likert scales will be used, instead of binary answers. Student satisfaction is measured with the Reliability test and other test results by Sultan and Wong [7] who propose seven questions, shown in table IV.

TABLE IV

VARIABLES RELATED TO SATISFACTION, SELECTED FROM SULTAN AND WONG [7].

\begin{tabular}{|ll|}
\hline \multicolumn{1}{|c|}{ Satisfaction } \\
\hline - & S1 Overall, I am satisfied with the service \\
performance & S2 Overall, I am satisfied with the quality relative to \\
price & S3 Overall, it is a good university \\
- & S4 Overall, I am satisfied with this university \\
- & S5 Overall, this university fulfills my needs \\
- & S6 Overall, this university provides satisfaction \\
compared to an alternate higher education institution \\
- S7 It has been a good decision to select this \\
university
\end{tabular}

S2 will not be included because price is not considered in this research; S6 will not be included because not all students know alternate higher education institutions.

Social influence is measured with the instrument by Un Jan and Contreras [21] with the variable subjective norm, as shown in table $\mathrm{V}$.

TABLE V

VARIABLES RELATED TO SOCIAL INFLUENCE, FROM UN JAN AND CONTRERAS [21].

\begin{tabular}{|ll|}
\hline \multicolumn{1}{|c|}{ Subjective norm } \\
\hline- & $\begin{array}{l}\text { Many persons who are important for my career } \\
\text { would approve that I study at this university }\end{array}$ \\
\hline - & $\begin{array}{l}\text { Many persons who are important for my career } \\
\text { would encourage that I study at this university }\end{array}$ \\
\hline
\end{tabular}

A first draft of the survey for this research was used among a group of undergraduate students in Peru (Spanish version) to validate the questions. The first draft design of the survey was run, tested and validated. A second and final version of the survey was finally used.

\section{B. Sample and survey}

Two private universities in Lima, Peru, were selected for this study. The sample size was calculated using equation 1 :

$$
\mathrm{n}=\mathrm{z}^{2} \sigma^{2} / \mathrm{d}^{2}
$$

Where $\mathrm{z}=1.96$ for $95 \%$ confidence, $\sigma=4$ points in the survey scale, and $d=1$ point in the survey scale. The sample size is $n=62$.

Students from two private universities in Lima, Peru, were requested to answer the questionnaire. The survey was run in classroom, the students were given enough time to fill in the answers, all the answers were numbers in a 5 point Likert scale. At one university, students from three different courses were invited to answer the questionnaire, and 63 students participated; at the second university, students from only one course answered the questionnaire, 21 students participated. The final sample size was 84 and all answers were used.

\section{RESULTS}

Table VI describes the sample. Students from two private universities in Peru, four different courses, were asked to fill in the survey. Reliability test using Cronbach's alpha gave values from 0.708 to 0.908 , which represent a reliable model. Correlation results in table VII confirm following hypotheses (numbers in bold face): $\mathrm{H} 1$, H2, H3a, H4a, H3b, H4b, H5a, H5b, and H6a. However, $\mathrm{H} 6 \mathrm{~b}$ is not confirmed: Reputation of the university has no influence on Intention to stay. 
TABLE VI

SAMPLE SIZE: 84 STUDENTS

\begin{tabular}{|l|c|}
\hline \multicolumn{1}{|c|}{ Age } & Students \\
\hline Age $<20$ years & 30 \\
\hline $20<=$ Age $<25$ & 44 \\
\hline Age: No answer & 10 \\
\hline
\end{tabular}$\quad$\begin{tabular}{|l|c|}
$\mid$ Male & Gender \\
\hline Female & 31 \\
\hline Gender: No answer & 13 \\
\hline
\end{tabular}

TABLE VII

CORRELATION MATRIX

\begin{tabular}{|l|c|c|c|c|c|c|c|c|c|}
\hline & $\alpha \mathrm{Cr}$ & QS1 & REP & QS2 & QP & IntStay & IWOM & CS & SN \\
\hline QS1 & 0.717 & 1 & 0.636 & 0.497 & 0.694 & 0.618 & 0.621 & 0.654 & 0.503 \\
\hline REP & 0.756 & & 1 & 0.512 & 0.629 & 0.515 & 0.597 & 0.715 & 0.521 \\
\hline QS2 & 0.799 & & & 1 & 0.596 & 0.376 & 0.430 & 0.576 & 0.415 \\
\hline QP & 0.747 & & & & 1 & 0.616 & 0.646 & 0.714 & 0.558 \\
\hline IntStay & 0.708 & & & & & 1 & 0.679 & 0.674 & 0.655 \\
\hline IWOM & 0.865 & & & & & & 1 & 0.697 & 0.666 \\
\hline CS & 0.908 & & & & & & & 1 & 0.653 \\
\hline SN & 0.907 & & & & & & & & 1 \\
\hline
\end{tabular}

\begin{tabular}{|l|l|}
\hline QS1 & Quality of service: academic \\
\hline REP & Reputation \\
\hline QS2 & Quality of service: administrative \\
\hline QP & Quality of product \\
\hline
\end{tabular}

\section{DISCUSSION}

\section{A. Final model}

The correlation matrix shows the relationship between social influence and other variables in the model, namely: Customer satisfaction, Intention to stay, and Intention to recommend. Social influence is related to Customer satisfaction: Social influence determines what the customer expects in terms of satisfaction. Social influence is related to Intention to Stay: Students depend on what others say. For some students, their parents pay the expenses. In other cases, students' families expect the student to finish the career. Social influence is related to Intention to recommend: Students recommend their university as an answer to what others expect from them. Students consider others expect a positive recommendation answer from them. Social influence will be part of the model. The high correlation $(r>0.6)$ is used to identify other variables in the model, to which social influence is related. Social influence is related to the two variables inside loyalty: Intention to stay and Intention to recommend. The new final model is shown in fig. 2.

\section{B. Limitations}

This research was done among students at private universities in Lima. Public universities were not included.

Economic factors and costs were not found in previous researches; the models previously investigated by other authors [7] [8] [11] [15] [19] [20] [22] focus on

\begin{tabular}{|l|l|}
\hline IntStay & Intention to Stay \\
\hline IWOM & $\begin{array}{l}\text { Intention to recommend: } \\
\text { Word of mouth }\end{array}$ \\
\hline CS & Customer satisfaction \\
\hline SN & Subjective norm \\
\hline
\end{tabular}

quality and customer satisfaction. Economic factors and costs are not included in this study.

Leaving the university and moving to another one, is not an easy process. Therefore, loyalty is also a matter of avoiding paperwork, and avoiding the risk of not getting the complete equivalence of courses. Paperwork was not mentioned in this research. However, in a study by Bowden [23], her results indicate that students reject the notion of loyalty determined by inertia and high switching costs.

\section{Future research}

This study has been applied to undergraduate students. The same study could be applied to post graduate students. Variables mentioned in the limitations and not included in this research might also be included in a next research.

\section{Administrative interpretation}

Loyalty in education, as in any other business, is necessary to keep clients, in this case students. Loss of students has been a problem for universities in Peru. From the resulting model in fig. 2, both perceptions of quality of the product and quality of the service need to be improved. Also, administrative and academic authorities must devote resources to improve customer satisfaction and reputation. Results must be measured on two variables that conform loyalty: Intention to stay and intention to recommend. 


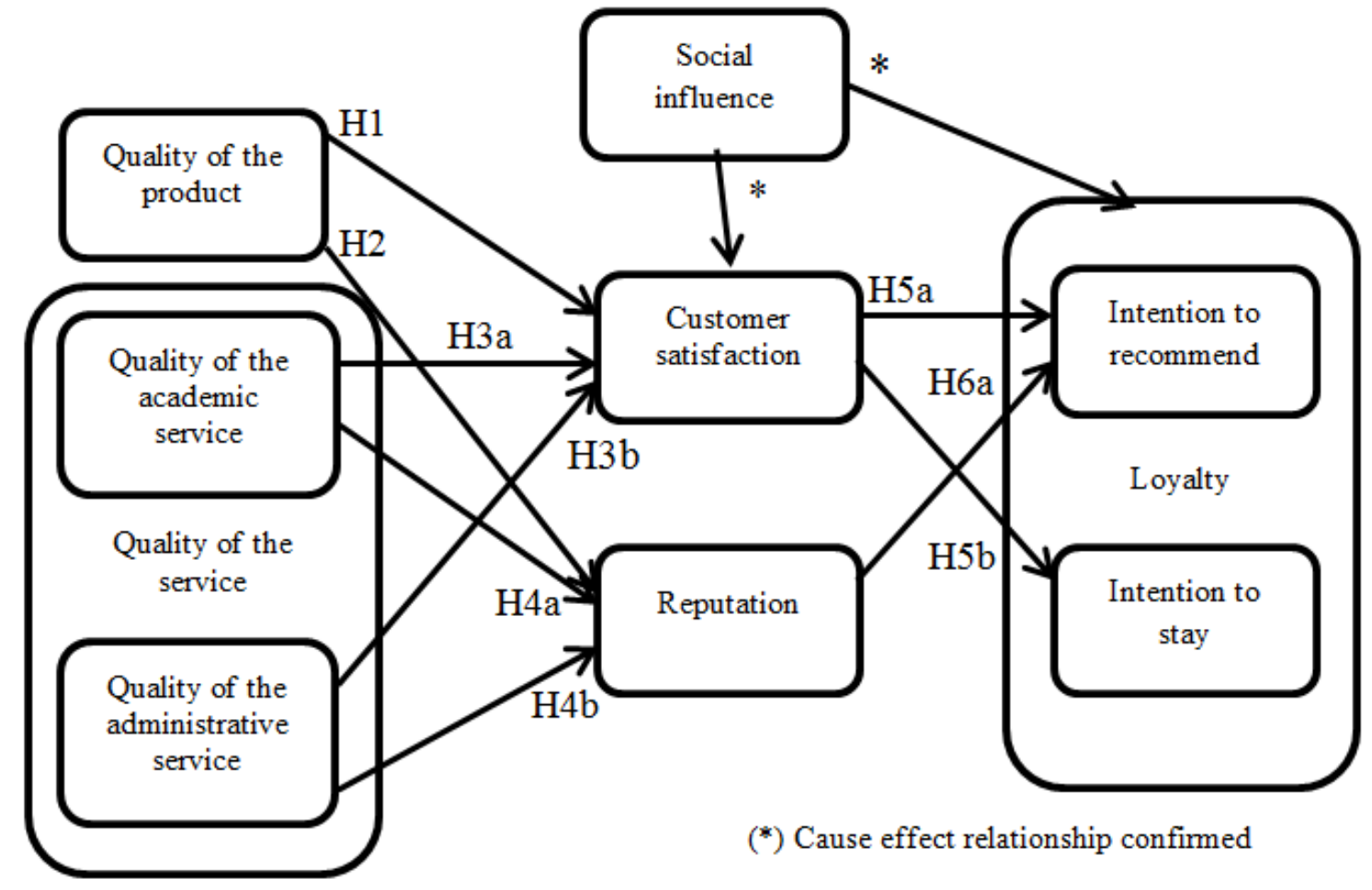

FIGURE 2

Final model

\section{CONCLUSIONS}

The purpose of this research is to examine the variables that influence on students' loyalty in education at the university, which is done by preparing a model to find the influence of quality on loyalty in education as a business. A questionnaire was developed to measure variables in the model. To improve loyalty, Quality of the product and Quality of the academic service are relevant. Loyalty is understood and measured as intention to recommend and intention to stay. Intention to recommend implies word of mouth, by verbal and electronic means. Intention to stay, as opposed to intention to flee, is better understood through this research.

Recommendations resulting from this model begin with quality. Improving quality of academic service and quality of administrative service will make the difference. One way for improving quality is through the Law of Education 30220, given in Peru in year 2014. This law regulates academic formation of professors, and activities in research. All universities in Peru must adapt their processes to this law; the adaptation will improve quality.

\section{ACKNOWLEDGMENTS}

This research began during the staff exchange done by doctor Un Jan at University of Ljubljana, Slovenia. The exchange was funded by Erasmus Mundus-SUDUE and supervised by professor doctor Aleš Popovič.

\section{REFERENCES}

[1] C. Peralta, C., "La deserción universitaria en Lima Metropolitana - estudio prospectivo," paper presented at Prospectiva sobre la deserción universitaria en Lima Perú, CLEIN XXII, 27 October - 01 November, Lima, Perú, 2013. Available

at: http://www.academia.edu/7909000/Prospectiva_sobr e_la_deserci\%C3\%B3n_universitaria_en_Lima-Peru (accessed 06 July 2016)

[2] Universidad Abierta Para Adultos [UAPA], Deserción en las instituciones de educación superior a distancia en América Latina y el Caribe, Ediciones UAPA, Santiago, República Dominicana, 2009.

[3] M. Mori, "Deserción universitaria en estudiantes de una universidad privada de Iquitos," Docencia Universitaria. Año 6 No. 1. Universidad Peruana de Ciencias Aplicadas, 2012. Available at:

http://www3.upc.edu.pe/html/0/boletines/ridu/articulo4-desercion-estudiantil-mori.pdf (accessed 06 July 2016)

[4] M. Heredia Alarcón, M. Andía Ticona, H. Ocampo Guabloche, J. Ramos-Castillo, A. Rodríguez Caldas, C. Tenorio, and K. Pardo Ruiz, "Deserción estudiantil en las carreras de ciencias de la salud en el Perú," Anales de la Facultad de Medicina, vol. 74, Lima 2015. 
[5] A. Caza and J. Wayne. "Effects of a holistic, experiential curriculum on business students' satisfaction and career confidence," The International Journal of Management Education, vol. 13, no. 1, pp. $75-83,2015$.

[6] M. Mohamad and Z. Awang, "Building corporate image and securing student loyalty in the Malaysian higher learning industry," The Journal of International Management Studies, vol. 4, no. 1, pp. 30-40, 2009

[7] P. Sultan and H. Wong, "Service quality in a higher education context: an integrated model," Asia Pacific Journal of Marketing and Logistics, vol. 24, no. 5, pp. 755-784, 2012.

[8] G. LeBlanc and N. Nguyen, "Searching for excellence in business education: an exploratory study of customer impressions of service quality," International Journal of Educational Management, vol. 11, no. 2, pp. 72-79, 1997.

[9] J. De Jager and G. Gbadamosi, "Predicting students' satisfaction through service quality in higher education," The International Journal of Management Education, vol. 11, no. 3, pp 107-118, 2013.

[10] F. Ahmed, R. Illahe, N. Ahmad, M. Nadeem, and K. Rehman, "Impact of student's satisfaction on loyalty. A case of private sector business schools from Punjab Pakistan," Journal of Marketing and Consumer Research, vol. 15, pp. 154-159, 2015.

[11] B. Al-Alak, "The impact of marketing actions on relationship quality in the higher education sector in Jordan," Journal of Marketing for Higher Education, vol. 16, no. 2, pp. 1-23, 2006.

[12] S. Phadke, "Modeling the determinants of student loyalty in Indian higher education setting," International Conference on Management, Behavioral Sciences and Economics Issues. ICMBSE'2011, pp. 262-264, 2011.

[13] M. Endres, S. Chowdhury, S., Frye, and C. Hurtubis, "The multifaceted nature of online MBA student satisfaction and impacts on behavioral intentions," Journal of Education for Business, pp. 304-312, May/June 2009.

[14] C. Chuah, and S. Ramalu, "Students satisfaction towards the university: Does service quality matters?" International Journal of Education, vol. 3 no. 2, pp. 1-15, 2011.

[15] E. Nesset and $\varnothing$. Helgesen, "Modelling and managing student loyalty: A study of a Norwegian university college," Scandinavian Journal of Educational Research, vol. 53, no. 4, pp. 327-345, August 2009.

[16] J. Rojas-Méndez, A. Vásquez-Párraga, A. Kara, and A. Cerda-Urrutia, "Determinants of student loyalty in higher education: a tested relationship approach in Latin America," Latin American Business Review, vol. 10, pp. 21-39, 2009.
[17] Y. Chen, "The impact of marketing strategies and satisfaction on student loyalty: a structural equation model approach," International Education Studies, vol. 9 no. 8; pp. 94-104, 2016.

[18] A. Kunanusorn, and D. Puttawong, "The mediating effect of satisfaction on student loyalty to higher education institution," European Scientific Journal, vol. 1, pp. 449 - 463, October 2015.

[19] R. Brown, and T. Mazzarol, "The importance of institutional image to student satisfaction and loyalty within higher education," Springer Science + Business Media B.V. 2008 High Educ. vol. 58, pp. 81-95, 2009

[20] J. Balujeva, "EWOM communication in social media: A study of its antecedents in higher education context," Master thesis, Lappeenranta University of Technology, School of Technology, International Marketing Management, Finland, 2015.

[21] A. Un Jan, and V. Contreras, "Technology acceptance model for the use of information technology in universities," Computers in Human Behavior, vol. 27, no. 2, pp. 845-851, March 2011.

[22] E. Megan, C. Sanjib, C. Frye, and C. Hurtbis, "The multifaceted nature of online MBA student satisfaction and impacts on behavioral intentions," Journal of Education for Business, vol. 84, no. 5, pp. 304-312, 2009.

[23] J. Bowden, "Engaging the student as a customer: A relationship marketing approach," Marketing Education Review, vol. 21, no. 3, pp. 211-228, 2011.

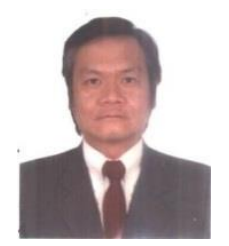

Alberto Un Jan, is engineer in electronics from Universidad Nacional de Ingeniería (UNI) in Lima, Perú. He holds an M.Sc. degree in systems engineering (UNI), M.Sc. degree in information and systems in manage ment from Sheffield City Polytechnic, UK; and a Doctor degree in engineering from Universidad Nacional Federico Villarreal, Lima, Perú. He has done research at Karl Franzens Universität, Graz, Austria, and University of Ljubljana, Slovenia. His research interest is in information systems and dynamic simulation.

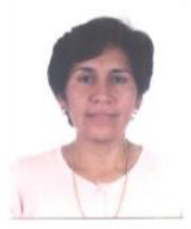

Vilma Contreras, is B.S. in systems engineering from Universidad Nacional de Ingeniería in Lima, Perú, she has studied for the M.Sc. degree in applied statistics at Universidad Nacional Agraria La Molina, Lima,

Perú. Her research interest is in statistical models.

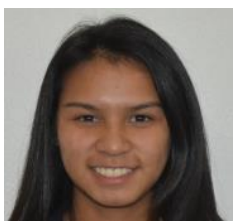

Vilma Un Jan, is B.S. in software engineering from Florida Gulf Coast University, USA. Her research interest is in machine learning and data mining. 